\title{
PILGRIMAGE IN THE CELTIC CHRISTIAN TRADITION
}

\author{
RODNEY AIST*
}

St George's College, Jerusalem

\begin{abstract}
This papers explores the diversity of pilgrim expressions in the Celtic Christian sources, focusing largely upon scriptural and theological images-namely, the image of Jerusalem, the example of Abraham, and journey as a metaphor for the earthly life. Discussion on Celtic interest in Jerusalem will focus on the text, De locis sanctis, by Adomnán of Iona (d. 704). Central to Abrahamic pilgrimage is the ideal of being a stranger, foreigner, exile and alien in the world. Columbanus (d. 615) and Columba (d. 597) are both described as pilgrims in the tradition of Abraham. The life of Patrick raises the question of the relationship between Abrahamic pilgrimage and the missionary life. The phenomenon of the seafaring monks, most famously St Brendan, will also be discussed through the lens of Abraham, while the corresponding text, The Voyage of St Brendan, will lead to a short discussion of liturgy as a form of pilgrimage. Finally, the lifelong journey of the Christian life-expressed through the metaphors of road and journey in the writings of Columbanus—will be discussed.
\end{abstract}

KEY WORDS: Celtic Pilgrimage, Jerusalem, Iona, Abraham, Columbanus

\section{Introduction}

For the Celtic Church, pilgrimage was a fundamental expression of the Christian life. Sources explicitly describe figures such as Columbus and Columbanus as pilgrims, Brendan is the quintessential voyaging monk, and the spiritual writings of Columbanus embrace the metaphors of road and journey. Today, modern pursuers of a Celtic Christian past embrace the image of pilgrimage. The idea of monks searching for their 'place of resurrection', reinforced by the idea of Celtic landscapes as 'tissue thin' locations linking the physical and spiritual realms, evokes the Christian imagination. American Protestants, for instance, otherwise reticent or at least unfamiliar with pilgrimage, are often at ease 'going on pilgrimage' to the British and Irish isles, something Protestant sensibilities otherwise limit mostly to Jerusalem. Activities largely consist of bus journeys, visits to historical sites, walks 
upon the landscapes, lectures on Celtic spirituality, a Celtic Eucharist and perhaps a few days in retreat.

These experiences are indeed pilgrimages in a modern sense, but they have practically nothing in common with pilgrimage in the age of the Celtic saints. Therefore, before discussing the particularities of pilgrimage in Celtic Christianity, we need to start with some foundational questions-what exactly is pilgrimage in the first place? How is pilgrimage defined? How has it been expressed over the centuries? Biblically, pilgrimage has been variously associated with the call of Abraham (Genesis 12: 1-2), with the Jewish festivals in Jerusalem, with the magi's journey to Bethlehem to worship the Christ child (Matthew 2: 1-12) and with New Testament references to Christians as strangers and aliens in this earthly life (cf. 1 Peter 2: 11). Throughout Christian history, pilgrimage has ranged from physical travels to the earthly city of Jerusalem to a spiritual metaphor of the Christian life. In the end, while themes of journey and destination are central to most understandings of pilgrimage, no single definition adequately defines the phenomenon. Rather, pilgrimage is better regarded as a rubric of the Christian life, under which falls a number of behaviors and expressions, thoughts and images.

The purpose of this paper is to explore the diversity of pilgrim expressions as they appear in the Celtic Christian sources. Rather than attempt an exhaustive survey of the subject, the paper will largely focus upon key scriptural and theological images that inspired pilgrim images and practicesnamely, the image of Jerusalem, the example of Abraham, and journey as a metaphor for the earthly life. Like other parts of the Christian world, destination-driven journeys to specific holy places-often to local sites-was the most common practice of pilgrimage in the Celtic world. There, at holy sites, the pilgrim had particular access to the heavenly world, most notably encountered as the image of Jerusalem. Discussion on Celtic interest in Jerusalem will focus on the text, De locis sanctis (On the Holy Places), by Adomnán of Iona (d. 704). Secondly, the discussion will address pilgrim practices that are based upon the biblical model of Abraham. Central to Abrahamic pilgrimage, which is less focused upon specific destinations, is the ideal of being a stranger, foreigner, exile and alien in the world. Columbanus (d. 615) and Columba (d. 597) are both described as pilgrims in the tradition of Abraham. The life of Patrick raises the question of the relationship between Abrahamic pilgrimage and missionary activity. The phenomenon of the seafaring monks, most famously St Brendan, will also be discussed through the lens of Abraham, while the corresponding text, The Voyage of St Brendan, will lead us, thirdly, into a short discussion of liturgy as a form of pilgrimage. Finally, the lifelong journey of the Christian life-expressed through the metaphors of road and journey-appear in the writings of Columbanus. 
Brief attention will also be given to the penitentials as a resource for the Christian journey.

\section{Destination Jerusalem}

Like other parts of Christendom, destination-driven journeys to specific holy places, including tombs, high crosses and sacred wells, were the most common practice of pilgrimage in the Celtic world. Making personal supplication at these sites, for instance, at the relics of St Ninian of Whithorn or St Columba of Iona, was one of the ultimate goals of destination-driven pilgrimage. Notably, the vast majority of pilgrim activity was local or at most regional. Pilgrimage did not require long distances, and sacred topography, including consecrated churches and monasteries, was not a distant concept. The landscape was spotted with holiness, and local sites could be accessed. Rather, pilgrim focus concentrated on one's experience at the destination.

The essential character of a holy site was its position as a meeting place between heaven and earth, giving the pilgrim access to the spiritual realm of God. There, the pilgrim was able to experience a glimpse of the heavenly world, notably perceived as the city of Jerusalem, the quintessential biblical image of holiness. In the case of a saint's tomb, the deceased holy person was recognized as a citizen of heavenly Jerusalem and was understood to be spiritually present at the site, interceding to God on behalf of the faithful supplicant.

The image of Jerusalem certainly evoked the religious imagination of the Christian West, including the Celtic world. More accurately, we should think of Jerusalem in terms of two different cities. The first is the heavenly city of New Jerusalem, which is described in Revelation 21-22. New Jerusalem is a city of gold, precious stones and pearls. It is a city of splendid gates, beautiful walls and paved streets. A river-the River of Life-runs through the middle of the city. The Tree of Life rises from its two banks. The city is also conspicuous for what it does not have: no shadows, no tears, no curses and no temple. New Jerusalem is the abode of the heavenly realm. Its inhabitants include angels, saints, the gathering of the nations and, most importantly, the presence-and thrones-of the Living God and his son, the Lamb of God, who illuminates the city, casting splendor and glory all around.

New Jerusalem was understood as the final destination of the earthly life and, thus, entered only through one's death and resurrection. However, the city could be glimpsed upon occasion. Consecrated space, such as a church sanctuary, replicated certain images of New Jerusalem at least in the religious imagination. New Jerusalem could also be accessed through scriptures and temporarily experienced through the liturgy. 
The second Jerusalem was the physical, earthly city. Most importantly, earthly Jerusalem was the city of past biblical revelation-the city of Solomon, David and Jesus Christ. As the land upon which the incarnate God walked and, more specifically, as the location of the death and resurrection of Jesus Christ, the earthly city of Jerusalem had an unrivaled status in the Christian mind. As the setting of the acts of salvation, it assumed the cosmological status of the centre of the world. Jerusalem was biblically and cosmologically unique among all cities of the world.

Earthly Jerusalem was also a historical, contemporary-and thus, nonbiblical—city. This was the city since the New Testament period up to and including the present. Three episodes of the city's history are of particular significance for understanding Christian attitudes towards Jerusalem. First of all, the destruction of the Jewish Temple by the Romans in $70 \mathrm{CE}$ was understood by Christians as a fulfillment of Jesus' prophecies (cf. Matthew 24: 1-2, Mark 13: 1-2, Luke 21: 5-6). As the Christian movement shifted from a temple-based religion to a religious based upon a shared Eucharist in a community gathering, early Christianity adopted a very ambivalent attitude towards holy places. More specifically, Christianity saw the area of the former temple as cursed land-as a negative theological witness to God's new revelation in Christ.

The second significant episode in the history of the city was the three hundred years of Christian rule, known locally as the Byzantine period (325-636/8 CE). During this time, Christian attitudes towards holy places changed. The sites of Jesus' death and resurrection were located and developed. The ensuing complex of the Church of the Holy Sepulchre (dedicated $335 \mathrm{CE}$ ), commissioned by the Emperor Constantine (d. $337 \mathrm{CE}$ ), was built on the western hill of Jerusalem opposite the site of the former temple on the city's eastern hill. For Christians, the Holy Sepulchre was the embodiment of New Jerusalem on earth. During the three hundred years of Byzantine rule, Christian holy places were officially located, Christian churches and monasteries were built throughout the Holy Land, and the practice of Christian pilgrimage to Jerusalem was firmly established.

The third important episode in Jerusalem's history was the Arab Conquest in 636/8 CE. Although Muslim-Christian relations in the seventh century were largely benign, the Christian visitor to Jerusalem encountered a Muslim-controlled city. For the Christian West, the earthly city of Jerusalem was now both foreign and far away. However, despite the new Muslim presence, what Christians reported was almost exclusively in Christian termsthey saw the city through a filter that focused on the Christian monuments to the biblical past and a promised future.

Sometime in the second half of the seventh century, most likely in the 680 s, an enigmatic Gallic bishop by the name of Arculf journeyed to the 
Holy City of Jerusalem. For nine months, he was a frequent visitor to the sacred sites in Jerusalem and the Holy Land. His travels concluded with other stops such as Alexandria, Constantinople, and Italy. According to Bede, Arculf became shipwreck on the way home washing up on the British Isles where he eventually met Adomnán, the ninth abbot of Iona. After a series on conversations between the two, Adomnán produced a treatise on the holy places, De locis sanctis, based upon Arculf's eyewitness account and supplemented by literary sources contained in Adomnán's library at Iona (Adomnán 2002: 167-206).

De locis sanctis has received a lot of scholarly discussion in the last two decades, mostly debating the respective roles of the two figures, Arculf and Adomnán, and the overall purpose of the text. The text should properly be seen as the collaborative input of both churchmen. The heart of the Jerusalem material, particularly its details of the holy sites, is the reliable account of Arculf. With respect to the Holy Land, De locis sanctis is the most fulsome and detailed text on Christian Jerusalem during the Early Islamic period. The Jerusalem material in Book One focuses on four main areas: (1) the complex of the Holy Sepulchre containing the places of the Lord's death and resurrection, (2) the Jehoshaphat Valley, including the tomb of Mary and the cave of Gethsemane, (3) the area of Mount Sion, the traditional location of the Last Supper, Pentecost and the death of Mary, and (4) the Mount of Olives, including the place of the Lord's Ascension. Book Two describes Arculf's journeys in the Galilee and Alexandria, while Book Three includes stories from Constantinople and a final vignette regarding Mount Vulcano off the coast of Sicily.

Interlaced with Arculf's account of the topography of the Holy Land are Adomnán's own exegetical and theological interests. Adomnán's engagement with the material demonstrates Iona's attraction to the city of Jerusalem. Indeed, there was a strong desire among those 'on the edge of the world' to receive what others brought back from the Holy City-biblical insights and knowledge of the land, descriptions and measurements of the holy sites, souvenirs and relics, and stories of the pilgrim experience. De locis sanctis is a remarkable testimony of the local Celtic interest in Jerusalem and the effort of the abbot of Iona to ensure that the Jerusalem material was recorded and preserved for his community.

While aspects of the text clearly express the perspective of the recipient Celtic community, it is hard to fully separate the respective contributions of Arculf and Adomnán. In any case, the text combines aspects of both the earthly and heavenly cities, or, perhaps more accurately, images of New Jerusalem are imbued within the description of the earthly Christian city. For instance, resonating Revelation 21, the text depicts Jerusalem as a walled city without a temple-this is underscored by a reference to the location of 
the former temple. The intramural city is devoid of sites except for the complex of the Holy Sepulchre, and one could perhaps argue that the Church of the Holy Sepulchre housing the places of the Crucifixion and Resurrection are analogous to the thrones of God Almighty and the Lamb. The lack of shadow, another feature of New Jerusalem, is referenced with respect to the noonday sun on the summer solstice.

Images of the Holy City-its biblical past, its holy sites, its cosmological status and its holy relics-tantalized the imagination of the Celtic monk. De locis Sanctis is not only representative of Celtic interest in Jerusalem, it had a significant role in dissimilating images of Jerusalem throughout the Christian West. Locally, the text, no doubt, influenced the liturgical experience on Iona. For instance, the book of Psalms, which was read in its entirety in the weekly liturgical cycles, has repeated references to Jerusalem. Those who knew the contents of De locis sanctis - its details of the biblical past, its reference to the Christian Holy Land, its imagery of New Jerusalemwould never hear the Psalms the same. In short, through text and liturgy, New Jerusalem and earthly Jerusalem met in the monastery of Iona. Jerusalem pilgrimage found a home on the island monastery.

\section{Abrahamic Pilgrimage}

Understandings of pilgrimage commonly focus upon the sacred components of journey and destination. Whether to a saint's shrine at a local monastery or to the Holy City of Jerusalem, this type of pilgrim journeyed to a holy place and, as a norm, returned home. However, the practice of pilgrimage included more than return-trip journeys to a holy place, and the diverse nature of pilgrimage becomes clearly apparent when we turn to the model of Abraham. Abraham is often considered to be the first biblical pilgrim and has similarly served as a prototype of Christian pilgrimage. As we will see, the Abrahamic model is significantly different from Jerusalem pilgrimage or other destination-driven journeys.

The call of Abraham in Genesis 12: 1-3 certainly entailed journey and destination:

Go from your country and your kindred and your father's house to the land that I will show you. I will make of you a great nation, and I will bless you, and make your name great, so that you will be a blessing. I will bless those who bless you, and the one who curses you I will curse; and in you all the families of the earth shall be blessed.

The land that God showed Abraham was the land of Canaan, and it took a journey to get there from Abraham's initial location in Haran. Moreover, once arriving in Canaan-passing through Shechem, Bethel, and the Negev-Abraham continued to Egypt before eventually returning to the Ca- 
naanite hill country. Abraham lived for another hundred years, and not unexpectedly, he covered a lot of territory during his life. We find him based in Mamre and later at Be'er Sheva. He chased foreign kings all the way to Damascus, passing through Dan on the way. Abraham was eventually buried in the cave of Machpelah at Hebron. The patriarch's physical movements can thus be charted on a map and labeled as the pilgrimage of Abraham. To think in terms of the physical movements of one's earthly life has come to be recognized as a category of pilgrimage, but this understanding is not what defines Abrahamic pilgrimage.

We could look at Abraham's life in a different way. During the last century of his life-from the time he left his homeland of Haran until his deathAbraham's life was difficult and obstacle-filled. God's promises took a long time to be realized. Thus, rather than think in terms of Abraham's physical journeys (where he traveled) one could think in terms of the events and narratives of his life (what happened to him, how he reacted). In other words, we could regard Abraham's pilgrimage in metaphoric terms as the trials and travails of his earthly life. This understanding of pilgrimage finds expressions in the sermons of Columbanus, which employ the metaphor of road and way for the mortal life, which will be discussed below as a separate category of pilgrimage. However, the metaphor of journey is not the defining characteristic of Abrahamic pilgrimage.

The essential nature of Abrahamic pilgrimage, or pilgrimage based upon the example of Abraham, has little to do with either his physical movements or with metaphors of the earthly life. Rather, Abrahamic pilgrimage, based upon God's call in Genesis 12, describes the state of living outside of one's homeland. The concept is as simple as leaving home and as specific as living in a foreign land. Abrahamic pilgrimage embraces the concept of the stranger, foreigner, exile and alien as a norm for the Christian life.

The Genesis narrative explicitly describes Abraham and his descendants as aliens (Genesis 15: 13, Genesis 17: 8, Genesis 21: 23; cf. with Acts 7:6). Upon the death of Sarah, Abraham declared in the presence of the Hittites at Hebron: 'I am a stranger and an alien residing among you' (Genesis 23: 4). An Abrahamic pilgrim is a guest in someone else's homeland.

This theme of foreignness is picked up by the writer of Hebrews:

By faith Abraham obeyed when he was called to set out for a place that he was to receive as an inheritance; and he set out, not knowing where he was going. By faith he stayed for a time in the land he had been promised, as in a foreign land, living in tents, as did Isaac and Jacob, who were heirs with him of the same promise (Hebrews 11: 8-9).

This expression of the Christian life-living in a foreign land-did not preclude a desire for the heavenly homeland, and with images resonant of New 
Jerusalem, Hebrews continues, 'For [Abraham] looked forward to the city that has foundations, whose architect and builder is God' (Hebrews 11: 10).

Two significant aspects of the Abrahamic model distinguish it from destination-driven pilgrimage. While the goal of the latter is a recognized holy place, in the Abrahamic model, the destination is a foreign, mostly unknown, location. Moreover, most destination-driven pilgrims make a complete return trip-that is, they return home. By contrast, for the most part, Abrahamic pilgrimage is a permanent and lifelong status; one usually does not return home. The Latin term for pilgrimage, peregrinatio, refers to the state of living away from one's homeland, and under Roman law foreigners had diminished rights and less legal protection. Thus, 'exiles for Christ' identified themselves as peregrini pro Christo. Abraham was the model for peregrinatio pro Christo as a form of the Christian life.

\section{Columbanus and Continental Europe}

The Abrahamic model of the Christian life was embraced by the Insular world of Ireland and Britain. According to Jonas' Vita Columbani 9, after Columbanus (d. 615 in Bobbio, Italy) 'had been many years in the cloister [in Ireland] he longed to go into strange lands, in obedience to the command which the Lord gave Abraham: "Get thee out of thy country, and from thy kindred, and from thy father's house, into a land that I will show thee".' (Jonas 1897-1907)

Columbanus' destination was continental Europe, and he left Ireland to found monasteries in France and Italy. He disputed bishops and the pope (Abraham engaged with kings and the pharaoh), and visited major cities of Western Europe. Columbanus, who journeyed from Ireland to Continental Europe, clearly imitated the life of the Abraham, and his biographer Jonas explicitly based his motives for leaving Ireland upon the call of Abraham in Genesis 12. As an Irishman in France and Italy, Columbanus lived out his life as a stranger and alien in a foreign land. He was in voluntary exile for God.

Other monks, such as Kilian (d. 689, Würzburg) and Fergal (d. 784, Salzburg), similarly left Ireland for Europe-their journeys took them from the edge of Christian Europe to the heartland of the Continent. Together, their movements underscore the point that Abrahamic pilgrimage was, most simply, about living as a stranger in a foreign land; it was neither about visiting holy places or inherently about seeking remote destinations.

Like the Irish, the Anglo-Saxons also promulgated a vision of the Christian life based upon Abraham. That the Abrahamic model did not necessitate a desolated destination is further underscored by the Anglo-Saxon attraction to Rome. Bede sums up the phenomenon: 'at this period, many English people vied with one another in following this custom [of going to 
Rome], both noble and simple, lay folk and clergy, men and women alike' (Bede 1990: V.7). The Abrahamic connection is explicitly named in the eighth-century Vita Sancti Wilfrithi. Wilfrid (d. c. 709), a Northumbrian bishop who had studied at the Iona foundation of Lindisfarne, refused an invitation to remain at Lyons while on a journey to Rome: 'I have made my vow to the Lord... leaving, like Abraham, my kinsfolk and my father's house to visit the Apostolic See, there to learn the laws of ecclesiastical discipline so that our nation may grow in the service of God'. Wilfrid would eventually return home to England bringing with him 'the holy relics he had collected in Rome' (Stephanus 1998: 109). The Anglo-Saxon phenomenon included kings as well as monks who permanently left England to live and die in the proximity of the tomb of St Peter. Among the Anglo-Saxon kings were Cadwalla in 688, Coenred in 709, and Ine in 726. Cadwalla went to Rome for baptism where he 'hoped to die shortly after his baptism and pass from this world to everlasting happiness. By God's grace, both of these hopes were realized' (Bede 1990: V. 7). Ine wished 'to spend some of the time of his earthly pilgrimage in the vicinity of the holy places, hoping thereby to merit a warmer welcome from the saints in heaven' (Bede 1990: V. 7).

So many Anglo-Saxons were based in the Eternal City that a neighborhood formed, the Schola Saxonum, allowing pilgrims to reside in perpetual exile near the tomb of St Peter. The Anglo-Saxon community in Rome underscores another common aspect of Abrahamic pilgrimage. Namely, having journeyed from one's homeland, Christians living out the calling of Abraham often settled upon a specific location where they practiced a life of monastic stability. Once one had forsaken their homeland, the Abrahamic calling had essentially nothing to do with further travel.

While leaving one's homeland and living in perpetual exile in a foreign land was the full expression of Abrahamic pilgrimage, as seen by Wilfrid's return to England, there were certain variations and qualifications to this ideal of the Christian life. Jonas' Vita Columbani records a conversation between Columbanus, before he left Ireland, and a devout holy woman living an eremitical life in the Irish countryside. The conversation articulates two degrees of pilgrimage-the lesser pilgrimage, which involved forsaking one's family but still living within one's native homeland, and the greater $e x$ patria pilgrimage, which required a journey across the sea. While the Patriarch is not explicitly mentioned, the theology of pilgrimage represented here is clearly based upon the Abrahamic narrative

The holy woman told Columbanus:

Twelve years have passed by, since I have been far from my home and have sought out this place of pilgrimage. With the aid of Christ, never since then have I engaged in secular matters; after putting my hand to the plough, I have not 
turned backward. And if the weakness of my sex had not prevented me, I would have crossed the sea and chosen a better place among strangers as my home (Jonas 1897-1907).

The conversation alludes to themes of worldly renunciation and the eremitical life which are important elements in the monastic tradition. However, while asceticism and the solitary life may be attached to the Abrahamic calling (see below), they are not intrinsic features of the Abrahamic model of pilgrimage. Rather, the holy woman was following in the footsteps of the Patriarch by living 'far from [her] home' and would have desired the full expression of the Abrahamic life by crossing the sea and living among strangers. Notably, having lived in the same 'place of pilgrimage' for twelve years, she was living a life of stability. As seen in the sources, how one orders his or her life is not a determinative characteristic of Abrahamic pilgrimage. The Anglo-Saxons in Rome lived in community, while the holy woman in Ireland lived as a hermit.

\section{Columba of Iona}

The legacy of Columba, the founder of Iona, also appeals to the Abrahamic ideal. According to the Old Irish Life of Columba:

God counseled Abraham to leave his own country and go in pilgrimage into the land which God has shown him, to wit the 'Land of the Promise'... Now the good counsel which God enjoined here on the father of the faithful is incumbent on all the faithful; that is to leave their country and their land, their wealth and their worldly delight for the sake of the Lord of the Elements, and go in perfect pilgrimage in imitation of him (Sheldrake 1995: 61).

According to the second preface of Adomnán's Vita Columba, 'In the second year following the battle of Cúl Drebene, when he was forty-one, Columba sailed away from Ireland to Britain, choosing to be a pilgrim for Christ' (Adomnán 1985: 105). Having settled on Iona, Columba lived a life of monastic stability; however, in line with the Abrahamic ideal, having left the land of his birth, Columba assumed the mantle of a lifelong pilgrim.

Two points emerge in the relationship to Columba's pilgrim identity. First of all, the historic motive for Columba's departure from his Irish homeland is uncertain. While Christian tradition would attribute spiritual motives for Columba's sojourn to Iona, it is quite possible that he left Ireland as a political exile. Secondly to use the criteria of the Vita Columbani, it is less clear whether Columba's move to Iona qualified as the greater pilgrimage. Since Columba had left his homeland and taken to the sea, his pilgrim credentials are not in doubt. However, the island of Iona, despite its proximity to mainland Britain, was under Irish control. While Columba 
would interact with Britons and Picts throughout his ministry, as the abbot of Iona he was not exactly living as a foreigner among foreign people. Nonetheless, notwithstanding issues of motive and location, Columba would emerge as a Christian exemplar of the Abrahamic ideal.

\section{St Patrick}

Dislocation was also fundamental to the biggest Celtic saint of all, St Patrick. Born in Britain, Patrick was kidnapped as a sixteen-year-old youth and taken to Ireland as a slave. Six years later, Patrick escaped Ireland and made his way back to his native land of Britain. There, he eventually heard a voice calling him to return to the land of his previous captivity, thus, returning to Ireland where he served God as a missionary bishop to the Irish people until his death.

Patrick's life strongly mirrored Abraham's example of serving God in a foreign land.

While no explicit references to Abraham are found in his writings, Patrick understood himself to be 'a servant of God to a foreign people' (Patrick 1999: 86). He had to speak an alien language (Patrick 1999: 69), live among men of an alien land (Patrick 1999: 67), and served God where he could not see any of his relatives (Patrick 1999: 86). The mantle of Abraham is easily applied to Patrick.

However, Patrick's explicit calling was missionary in focus. Patrick understood himself as a 'fisher of men' (Luke 5: 10), and following the Great Commission (Matthew 28:16-20), he went out to teach the nations, preaching the gospel to the entire universe. Specifically, he had been sent 'to the Irish nations to preach the gospel' (Patrick 1999: 76), in Ireland 'where they never had knowledge of God' (Patrick 1999: 78). For Patrick, the location of the Irish people was also of theological importance. Patrick's unique calling was to 'bring salvation to the uttermost parts of the earth' (Patrick 1999: $77)$ :

That I should in some way imitate those men to whom the Lord foretold what was about to occur when 'his gospel [of the kingdom will be preached throughout the whole world] as a testimony to all nations' before the end of the world. And this is what we see. It has been fulfilled. Behold! We are [now] witnesses to the fact that the gospel has been preached out to beyond where any man lives (Patrick 1999: 76).

These views of Patrick speak decidedly of the Celtic perspective of time and space. In terms of location, the British and Irish isles were at the very edge of the inhabited world. By contrast, the city of Jerusalem, the source of salvation, stood at the center. In terms of history, since the gospel had now been preached to the last nation, Patrick stood at the end of time. 
To be a pilgrim in the example of Abraham is merely to live in a foreign place, no particular activities are prescribed, and the Genesis account notably provides no indication of the teachings of Abraham. However, in the example of Patrick, Abrahamic pilgrimage and missionary activity are closely entwined. Columbanus and Columba were also, at least to some degree, engaged in Christianizing their surroundings, the later notably identified as a missionary to the Picts (Sharpe 1985: 30-33).

Can missionary activity be understood as pilgrimage without the Abrahamic imperative, that is, without leaving one's homeland? The idea is strongly affirmed in Jesus' sending out the Twelve, which is steeped in the image of journey. Jesus sent out the Twelve to preach the Kingdom of God and to heal the sick-'so they set out and went from village to village, preaching the gospel and healing people everywhere' (Luke 9: 6). Jesus' description of the missionary task is also the strongest biblical foundation for ascetic pilgrimage: 'Take nothing for the journey-no staff, no bag, no bread, no money, no extra tunic' (Luke 9: 3). In short, there is solid scriptural basis for understanding missionary activity as a form of pilgrimage, whether or not this activity is done in one's homeland or in a foreign land. In the Celtic tradition, St Patrick is the exemplar of the missionary pilgrim. While his missionary calling comes from the words of Christ, he locates himself in the tradition of the Abrahamic stranger.

\section{The Voyaging Monks of Ireland}

While the city of Rome, Continental Europe and even other locations in Ireland were various destinations linked to Abrahamic pilgrimage, monks were not always certain where they were going. Many took to the seas to be led where God would take them, while others were looking for a destination-a place of resurrection or a desert in the ocean-that they would recognition upon arrival. The Anglo-Saxon Chronicle for the year 891 describes the arrival of three Irishmen to the shores of Cornwall. Demonstrating their total dependence upon God, their transportation was a boat without any oars and provisions to last for a week. They had left Ireland 'because they wished for the love of God to be on pilgrimage, they cared not where' (Sumption 2002: 96).

The practices of the voyaging monk-one of the more distinctive expressions of early Irish Christianity-were again modelled upon the Abrahamic ideal. In the aforementioned example, the three oarless monks seem to be guided by a rather direct adherence to Genesis 12: 1: 'Go from your country... to the land that I will show you'. The monks were embracing two key elements of the Abraham narrative: total dependence upon God and an unknown destination. 
Despite the aimless wandering of these travelers, the voyaging monk was looking for a destination on dry land. A literal reading of Genesis 12_'Go... to the land that I will show you'-would indicate this. The sources are in agreement. According to the Vita Columba, a certain Cormac Ua Liatháin had labored upon the ocean three separate times in search of a place of retreat but had yet to find one $(V C$ 1.16). The ocean journey was a formative experience, lived out in prayer and monastic devotion. However, the goal of monastic voyaging was not the sea but rather a place to land.

Much like the Anglo-Saxon experience with Rome, the practice of ocean voyaging was not necessarily permanent. Here, links with the Abrahamic story are less exact. Having found their desert in the ocean-perhaps an island in the sea-monks spent a period of time in retreat before returning home.

This is exactly the case with Ireland's most famous voyaging monk, St Brendan of Clonfert (d. c. 577). In The Voyage of St Brendan, Ireland's medieval best seller, Brendan and a boatful of monastic companions sailed the ocean in search of the Promised Land of the Saints, which they successfully discovered after a seven-year circuitous journey that finds the monks visiting many of the same islands in an annual pattern. The monks repeatedly encounter an island of sheep, a paradise of birds, and a whale, Jasconius, where they spend the Easter vigil. They also spend each Christmas on the same island. Their journey also takes them to an island of grapes, an island of blacksmiths and a silver pillar in the sea. They encounter various sea creatures, survive a volcano and meet the figures of Judas and Paul the Hermit. While the text has been extensively examined as a source for the navigational history of the North Atlantic, particularly to identify locations described in the story, the point is that these are monks-not explorers or merchants-who are making the journeys depicted in the text. In other words, monks setting out to sea was a religious activity. It was an act of faith, an expression of the Christian life, a practice of pilgrimage.

\section{Liturgical Journeys}

While The Vyage of Saint Brendan represents the phenomenon of real monks making actual physical journeys upon the sea in search of a desert in the ocean, the text above all expresses the liturgical imagination of the Celtic world. It does so in terms of pilgrim images and spiritual movement, particularly following the pattern of the annual liturgical cycle. The Voyage of Saint Brendan is less a story of the personal Christian journey than it is a image-rich celebration of the religious common life. While the text depicts certain individuals - who respectively ascend to heaven or descend to hellits emphasis is on the shared corporal journey of the Body of Christ. Brendan's boat represents the ark of the Church at times adrift in the world. 
Through the grace of Christ, the monks are sustained on their journey and arrive victorious, after much perseverance, at their hoped-for destination, the Promised Land of the Saints, which is based upon the image of New Jerusalem. While New Jerusalem can only be ultimately accessed through one's death and resurrection, liturgy temporarily transcends both time and space. In the end, the monks have to leave the Promised Land of the Saints and return home. The Voyage of Saint Brendan espouses a theology of liturgy which embraces worship as a journey of the earthly church. The goal of earthly liturgy is to be in concert with the perpetual liturgy of the heavenly court. Through the mystery of liturgy, the Church journeys through an uncertain world while it simultaneously transcends the spiritual dimensions of its future heavenly home.

\section{Pilgrimage and the Earthly Life}

Distinct from liturgical practice, the earthly life as a whole has long been described by the metaphor of journey. Since the earthly life is an embodied experience-and, for example, the travails of this life are often physical depravations-pilgrimage as the earthly life is not always pure metaphor. One's life journey may be hard due to actual poverty or disease. One's spiritual life is affected by real events. In sum, this image of pilgrimage sees the earthly life in terms of a single journey from the cradle to the grave-a journey beset with both physical and spiritual challenges along the way.

In the Celtic sources, pilgrimage as the earthly life is best expressed in the sermons of Columbanus (Columbanus 1999: 353-356). The human life is a journey on a road, and the destination is life with God in the heavenly homeland. In Sermon Five, Columbanus describes the human journey as temporary, swift, difficult and full of anxiety. The earthly life is 'to be walked on and not lived in, so that they who walk upon it may dwell finally in the land that is their home'. The Christian is to travel 'anxiously', 'carefully', and 'hastily' through the mortal life 'like wayfarers, to their true homeland'. Columbanus compares the earthly journey with the heavenly home: 'for effort and fatigue are to be found on the journey, while peace and safety are prepared in the land that is our home'. He also contrasts the heavenlyminded Christian traveler with those who are in love with the earthly world: 'There are many who are so at ease on this journey that they seem not so much to be wayfarers as to be already at home, and they travel unwillingly rather than freely toward a home that is from them already lost' (Columbanus 1999: 353-354).

In Sermon Eight, Columbanus begins by describing the general nature of a journey, and then applies it to the Christian life. It is "natural for travelers to hurry on to their homeland; it is natural too that they should experience anxiety on the roadway and peace when they arrive home'. Similarly, the 
Christian who is on the earthly road should 'hasten on, for the whole of our life is like one day's journey'. The task of the Christian pilgrim is 'to love the things above, to desire the things above, to relish the things above and to seek our home there, for the fatherland is where our Father is'. In other words, Christians 'have no home on earth, since our Father is in heaven'. While concerning one's self with divine things, pilgrim virtues include hope, longing and perseverance: Christians, 'like pilgrims, continuously sigh for and long for our homeland, for travelers are always filled with hope and desire for the road's end' (Columbanus 1999: 354-356).

While Columbanus depicts the Christian as homeless in the earthly world, the language of 'alien' or 'exile' does not appear in these sermons. He does, however, describe Christians as 'guests of the world': 'Let us keep to this principle, therefore, that we should live as travelers and pilgrims on the road, as guests of the world, free of lusts and earthly desires, but let us fill our mind with heavenly and spiritual forms' (Columbanus 1999: 353).

Columbanus' image of the Christian life is further discussed in his own monastic Rule. In his comments on food and drink, Columbanus raises the possibility of 'spiritual progress', a concept that adequately conveys the idea of spiritual pilgrimage. His stance is one of moderation: 'Use of life must be moderated just as labor must be moderated, since this is true discretion that the possibility of spiritual progress may be kept alive by an abstinence which punishes the flesh. For if abstinence goes too far, then it will be a vice and not a virtue' (Columbanus 1999: 248). While the Christian should be satisfied with the bare minimum, the life of faith was not characterized by extremism (Columbanus 1999: 248). Wise judgment based upon the truth of God mattered more: "we must always proceed straight ahead by discernment, that is, by the light of God' (Columbanus 1999: 254).

Finally, it is worth briefly considering Celtic Christianity's most unique contribution to Western Christianity-the penitentials-to discern possible connections to pilgrim ideas. Despite their perceived austereness, the penitentials attempted to solve the theological dilemma of how to forgive sins that were committed after baptism. As an apparatus for Christian reconciliation with God, the penitentials helped ensure the salvation of the soul. Yet, in the Penitential of Cummean, for example, the text's central motif is not one of journey or progress but rather one of remedies, one of cures and balances. 'Contraries are cured by contraries. For they who do what is forbidden without restraint ought to restrain themselves even from what is allowed' (Cummean 1999: 231). In other words, the image is one of meeting in the middle rather than progressing forward. In sum, while penitentials were a valuable resource for keeping the earthly pilgrim on course, pilgrim images do not show up strongly in these texts. 


\section{Conclusion}

This paper has aimed to make two main points. The first point is that pilgrimage has numerous expressions and cannot be defined by a single definition. Rather, pilgrimage should be seen as a larger rubric of the Christian life which includes multiple images and practices. Secondly, the sources of Celtic Christianity provide an insightful case study for exploring the diverse nature of pilgrimage. Specifically, the paper has focused upon biblical and theological images of pilgrimage that appear in the Celtic sources. The city of Jerusalem spurred the religious imagination of the Celtic mind, which uniquely contemplated the Holy City from the far edges of the inhabited world. Moreover, the image of pilgrimage in Celtic Christianity is indelibly linked to the biblical example of Abraham, who left his homeland to serve God in a foreign land. The three central figures of Celtic Christianity, Columbanus, Columba and Patrick, all fit this pattern, as do Brendan and the seafaring monks. The heroes of the Celtic Church embraced the status of foreigner, alien and stranger. While pilgrimage meant actual journeys to foreign nations, these same themes of being an alien and a stranger were also fundamental to the metaphorical concept of pilgrimage and the earthly life.

For Celtic Christians, ideas of pilgrimage touched upon topics such as time and location, journey and destination, prayer and liturgy. Pilgrimage was physical and spiritual, earthly and heavenly, literal and metaphorical, individualistic and corporate. It embraced missionary activity and ascetic living. In many ways, for the Celtic Church, pilgrimage was nothing less than the Christian life itself.

\section{Bibliography}

Adomnán (2002) De locis sanctis. In Wilkinson J (ed) Jerusalem Pilgrimage Before the Crusades. Warminster: Aris \& Phillips.

Adomnán (1985) Vita Columba. In Sharpe R (ed) Adomnán of Iona. The Life of St Columba. London: Penguin Books.

Anon (1999) The Voyage of Saint Brendan. In Davies O, with O'Loughlin T (eds) Celtic Spirituality. Mahwah, NJ: Paulist Press.

Bede (1990) Historia ecclesiastica. In Sherley-Price L, revised by Latham RE (eds) Bede. Ecclesiastical History of the English People. London: Penguin Books.

Columbanus (1999) Sermons of Columbanus. In Davies O, with O'Loughlin T (eds) Celtic Spirituality. Mahwah, NJ: Paulist Press.

Columbanus (1999) The Rule for Monks by Columbanus. In Davies O, with O'Loughlin T (eds) Celtic Spirituality. Mahwah, NJ: Paulist Press. 
Cummean (1999) The Penitential of Cummean. In Davies O, with O'Loughlin $\mathrm{T}$ (eds) Celtic Spirituality. Mahwah, NJ: Paulist Press.

Eddius Stephanus (1998) Vita Sancti Wilfrithi. In Farmer DH, Webb JF (eds) The Age of Bede. London: Penguin Books.

Jonas (1897-1907) Vita Columbani. In Munro DC (ed) Translations and Reprints from the Original Sources of European history, volume 2, number 7 . Philadelphia: University of Pennsylvania Press. See http://legacy.fordham.edu/halsall/basis/columban.asp.

Patrick (1999) Confessio. In Davies O, with O'Loughlin T (eds) Celtic Spirituality. Mahwah, NJ: Paulist Press.

Patrick (1999) Epistola militibus Corotici. In Davies O, with O'Loughlin T (eds) Celtic Spirituality. Mahwah, NJ: Paulist Press.

Sharpe R (1985) Adomnán of Iona. The Life of St Columba. London: Penguin Books.

Sheldrake P (1995) Living Between Worlds. Place and Journey in Celtic Spirituality. London: Darton, Longman, and Todd.

Sumption J (2002) Pilgrimage. London: Faber and Faber. 